Tri Rahayu, Mohamad Ihsan \& Tri Pamujiasih, 2021. Modifikasi Media Tanam Untuk

Meningkatkan Mutu Bibit Handeuleum (Graptophyllum pictum L. (Griff.)) Dari Beberapa Macam Asal Stek. Journal Viabel Pertanian. (2021), 15(2) 83-92

\title{
MODIFIKASI MEDIA TANAM UNTUK MENINGKATKAN MUTU BIBIT HANDEULEUM (Graptophyllum pictum L. (Griff.)) DARI BEBERAPA MACAM ASAL STEK
}

Diterima:

04 Juni 2021

Revisi:

04 November 2021

Terbit:

19 November 2021

\author{
${ }^{1}$ Tri Rahayu, ${ }^{2}$ Mohamad Ihsan, ${ }^{3}$ Tri Pamujiasih \\ 1,2,3 Prodi Agroteknologi Fakultas Pertanian Universitas Islam \\ Batik Surakarta, Indonesia \\ Email : ${ }^{2}$ mohammad.xzan@gmail.com
}

\section{ABSTRAK}

Penelitian berjudul "Modifikasi Media Tanam untuk Meningkatkan Kualitas Bibit Handeuleum (Graptophyllum pictum L.) dari Beberapa Jenis Sumber Stek", dilakukan di Sukoharjo, Jawa Tengah. Perlakuan pertama adalah jenis stek sumber yaitu: stek pucuk (S1), stek dari bagian kedua (S2), dan stek dari bagian ketiga (S3). Faktor perlakuan kedua adalah jenis media: media tanah berpasir (M1), media rockwool (M2), dan media cocopeat (M3). Data yang diperoleh dianalisis dengan uji F pada taraf nyata 5\% dan 1\%, sedangkan uji lanjutan dilakukan dengan uji jarak berganda Duncan pada taraf nyata 5\%. Hasil yang diperoleh menunjukkan bahwa perlakuan $S$ (jenis sumber stek) berpengaruh nyata terhadap variabel jumlah cabang, jumlah daun, dan luas daun setiap semai. Jumlah cabang dan daun tertinggi dicapai pada perlakuan S3 (stek bagian ketiga), diikuti oleh perlakuan S2 (stek bagian kedua) dan S1 (stek pucuk). Ada perbedaan yang signifikan antara perlakuan. Pada variabel luas daun, hasil tertinggi dicapai pada S1 (stek pucuk), diikuti oleh S2 dan S3 yang berbeda nyata. Perlakuan sumber stek tidak menunjukkan pengaruh yang nyata terhadap variabel waktu munculnya mata tunas, bobot segar daun dan bobot kering daun. Perlakuan berbagai media memberikan pengaruh yang nyata terhadap variabel luas daun masing-masing semai. Media cocopeat (M3) menghasilkan luas daun tertinggi, diikuti oleh perlakuan M1 (media pasir), dan M2 (media rockwool). Tidak ada interaksi antara perlakuan jenis sumber stek dan jenis media untuk semua variabel yang diamati.

Kata kunci: pemagkasan, handeuleum, media, bibit.

\section{ABSTRACT}

The research titled "Modification of Planting Media to Improve the Quality of Handeuleum (Graptophyllum Pictum L.) Seedling from Several Kinds of Cuttings Source", was conducted in Sukoharjo, Central of Java. The first treatment was the kind of cuttings source, namely: cuttings from the shoot $\left(S_{1}\right)$, cuttings from the second section $\left(\mathbf{S}_{2}\right)$, and cuttings from the third section $\left(\mathbf{S}_{3}\right)$. The second treatment factor was the kind of media: sandy soil media $\left(M_{1}\right)$, rockwool media $\left(M_{2}\right)$, and cocopeat media $\left(M_{3}\right)$. The data obtained were analyzed with the $F$ test at $5 \%$ and $1 \%$ significant levels, while the follow-up test was carried out using Duncan's multiple range test at the 5\% significant level. The results obtained indicated that the $S$ treatment (kind of cuttings source) had a significant effect on the variables of the number of branches, number of leaves, and leaf area of each seedling. The highest number of branches and leaves was achieved in the $S_{3}$ treatment (third section cuttings), followed by $S_{2}$ (second section cuttings) and $S_{1}$ (shoot cuttings) treatments. There were significant difference 
Tri Rahayu, Mohamad Ihsan \& Tri Pamujiasih, 2021. Modifikasi Media Tanam Untuk Meningkatkan Mutu Bibit Handeuleum (Graptophyllum pictum L. (Griff.)) Dari Beberapa Macam Asal Stek. Journal Viabel Pertanian. (2021), 15(2) 83-92

between the treatments. In leaf area variables, the highest yield was achieved at $S_{1}$ (shoot cuttings), followed by $S_{2}$ and $S_{3}$ which were significantly different between each other. Treatment cutting source showed no significant effect on variable the appearance time of the buds, fresh weight of leaves and dry weight of leaves. The treatment of various media gave a significant influence on the leaf area variables of each seedling. Cocopeat media $\left(M_{3}\right)$ produced the highest leaf area, followed by $M_{1}$ (sand media), and $M_{2}$ (rockwool media) treatments. There was no interaction between treatments of kind of cuttings source and types of media for all observed variables. Keyword: cutting, handeuleum, media, seedling.

\section{PENDAHULUAN}

Tanaman daun ungu adalah nama lain dari handeuleum (Graptophyllum pictum L. (Griff.)). Daun tanaman ini banyak terkandung alkaloid yang tidak toksik, glicosida, steroid, saponin, tannin, khlorofil terrmasuk juga lendir. Di dalam batangnya banyak terkandung kalsium oksalat, asam formik, dan juga lemak. Hampir semua bagian dari tanaman ini bermanfaat sebagai obat yang mencakup dari bagian kulit batang, bagian daun, dan juga bunganya. Daunnya memiliki manfaat sebagai obat untuk mengatasi wasir (hemoroid) dan sembelit (konstipasi), sedangkan bunganya dapat dipakai untuk mengatasi haid yang tidak lancar (Dalimartha, 1999).

Akhir-akhir ini diketahui bahwa pengobatan dengan obat-obat kimia banyak memiliki dampak negatif, oleh karena itu banyak masyarakat yang beralih ke nature atau alami (Pramono, 2002). Pengobatan terhadap penyakit banyak menggunakan obat herbal yang berasal dari tanaman, hal ini menyebabkan permintaan terhadap bahan baku obat meningkat. Tidak ketinggalan permintaan bahan baku daun ungu juga meningkat. Tanaman handeuleum diperbanyak secara vegetatif dan generatif. Perbanyakan secara vegetatif berupa stek batang memiliki banyak keunggulan karena lebih mudah dan cepat serta diperoleh anakan yang memiliki sifat persis seperti induknya. Mrnurut Ashari (2006), berdasarkan kepada tipe jaringannya secara umum stek batang dapat dipilahkan ke dalam 4 kelompok ialah, hardwood, semihardwood, softwood dan herbaceous. Stek handeuleum termasuk ke dalam kelompok stek hardwood, dan untuk mendapatkan stek tanaman ini dapat diambilakan dari stek bagian pucuk, stek batang bagian tengah, ataupun stek asal dari bagian pangkal batang. Dalam melakukan perbanyakan melalui stek, maka salah satu metode sederhana yang dapat dilakukan adalah ketepatan dalam memilih asal stek yang akan ditumbuhkan. Pada tanaman handeuleum, untuk menghasilkan bibit dengan kenampakan vigor yang baik, sampai saat ini belum didapatkan informasi yang akurat, stek dari bagian mana pada batang handeuleum yang paling baik. Dalam memeperbanyak tanaman ini, semua asal stek handeuleum dari tanaman yang akan diperbanyak diharapkan dapat menghasilkan bibit yang memiliki vigor dengan pertumbuhan yang sama, sehingga tidak ada bagian tanaman yang tidak termanfaatkan.

Pada bagian pucuk tanaman terdapat titik tumbuh yang mengalami dominansi (sering disebut dominansi apikal) sehingga apabila dipakai untuk bahan stek akan tumbuh ke atas tanpa membentuk cabang. Bahan stek bagian yang lebih bawah mempunyai tunas lateral (tunas samping), akan aktif tumbuh apabila bagian pucuk sudah tidak ada. Stek dari bagian bawah ini dapat menghasilkan tunas lebih dari satu (Cline, 1999).

Untuk mencapai keberhasilan dalam menyiapkan stek agar tumbuh menjadi bibit tanaman yang baik, perlu didukung oleh ketersediaan dan kesesuaian pada media tanamnya, karena media tanam berperan di dalam pembibitan tanaman sebagai tempat tumbuh dan berkembangnya perakaran (Pasetriyani, 2014). Media tanam juga memiliki 
Tri Rahayu, Mohamad Ihsan \& Tri Pamujiasih, 2021. Modifikasi Media Tanam Untuk Meningkatkan Mutu Bibit Handeuleum (Graptophyllum pictum L. (Griff.)) Dari Beberapa Macam Asal Stek. Journal Viabel Pertanian. (2021), 15(2) 83-92

sifat yang tidak sama dalam menyimpan air. Ada kelompok media tanam yang sifatnya dapat menyimpan air lebih banyak sehingga menyebabkan batang bibit bagian stek bawah dan akarnya mengalami pembusukan. Ada pula kelompok media tanam dengan kemampuan menahan air yang rendah, sehingga media ini cepat kering yang mengakibatkan bibit cepat mati. Media tanam yang baik adalah media yang dapat menyimpan air sekaligus juga menyediakan unsur hara dalam jumlah yang cukup dan berimbang bagi pertumbuhan bibit. Hal ini dapat dicapai apabila tanah memiliki porositas yang mampu mendukung sirkulasi udara dan air secara berimbang, memiliki agregat yang mantap, kemampuan menahan air yang baik dan ruang yang cukup untuk perkembangan akar.

Cocopeat adalah salah satu media tanam yang dihasilkan dari proses perusakan sabut kelapa. Pada proses penghancuran sabut untuk mendapakan serat yang nantinya akan digunakan untuk berbagai keperluan (dibuat tali, sapu, keset dll.) akan didapatkan bubuk halus yang disebut sebagai cocopeat. Bubuk inilah yang dapat dimanfaatkan sebagai media penyapihan karena memiliki kemampuan dalam menyerap air dan memperbaiki struktur tanah agar menjadi lebih remah (Anonymous, 2014). Cocopeat sebagai media tanam memiliki kelebihan selain karena kemampuannya dalam mengikat air dan menyimpannya secara kuat, juga banyak mengandung unsur-unsur hara yang dibutuhkan tanaman yang mencakup: kalsium $(\mathrm{Ca})$, magnesium $(\mathrm{Mg})$, kalium $(\mathrm{K})$, natrium $(\mathrm{Na})$, dan juga fosfor. Disamping itu cocopeat juga dapat menetralkan kemasaman tanah (Prayugo, 2007 cit. Mariana, 2017). Yang harus diperhatikan bahwa cocopeat sebagai sabut kelapa memiliki kandungan $\mathrm{Cl}$ tinggi yang dapat menghambat pertumbuhan tanaman (Irawan dan Kafiar, 2015).

Rockwool adalah media anorganik sintetik dengan komponen media berbentuk butiran yang memiliki kemampuan untuk menyerap dan meneruskan air. Rockwool memiliki daya pegang dan kapasitas menahan air yang tinggi hingga 14 kali lipat kapasitas menahan air dari tanah. Sifat lain dari rockwool adalah ramah lingkungan serta tidak mengandung patogen. Rockwool dibuat dari batuan yang biasanya mengandung sejumlah besar mineral alkali, oleh karena itu pH rockwool juga cenderung tinggi (antara 7,8 - 8.0).

Tanah pasir adalah tanah yang didominasi oleh butiran mineral berupa partikel yang besar. Tanah ini merupakan hasil dari pelapukan batuan beku dan sedimen yang memiliki ukuran besar dan kasar atau sedang sering disebut sebagai kriket. Tanah pasir memiliki nilai yang rendah daya serap air karena terdiri dari sebagian besar partikel berukuran 0,02-2 $\mathrm{mm}$ dengan dominasi pori-pori makro (Muhit dan Qodriyah, 2006).

\section{METODE PENELITIAN}

Percobaan dilakukan di Green house UNIBA di Sukoharjo dengan ketinggian tempat $\pm 118 \mathrm{~m}$ dpl. Bahan yang digunakan dalam penelitian ini adalah: stek handeuleum, cairan pupuk, cocopeat, rockwool, tanah pasir. Alat-alatnya berupa: polybag, alat pengukur, nampan pot, plastik kecil.

\section{Metode Penelitian}

Rancangan Acak Lengkap faktorial digunakan sebagai rancangan lapangan pada percobaan ini, dengan 2 faktor perlakuan yang dicobakan. Faktor poerlakuan pertama yaitu asal stek yang terdiri dari 3 macam sumber asal stek adalah: $S_{1}$ (stek dari bagian pucuk), $S_{2}$ (stek dari ruas ke dua), dan $\mathrm{S}_{3}$ (stek dari ruas ke tiga). Faktor perlakuan kedua adalah macam media tanam yang terdiri atas 3 macam yaitu: $\mathrm{M}_{1}$ (media pasir), $\mathbf{M}_{2}$ (media rockwool), dan $\mathrm{M}_{3}$ (media cocopeat). Oleh karena itu diperoleh sembilan kombinasi 
Tri Rahayu, Mohamad Ihsan \& Tri Pamujiasih, 2021. Modifikasi Media Tanam Untuk Meningkatkan Mutu Bibit Handeuleum (Graptophyllum pictum L. (Griff.)) Dari Beberapa Macam Asal Stek. Journal Viabel Pertanian. (2021), 15(2) 83-92

perlakuan yang pada setiap masing-masing perlakuan dengan tiga ulangan, dan setiap unit perlakuan terdiri atas lima sub ulangan.

\section{Implementasi}

Menyiapkan bahan-bahan untuk media tanam, larutan nutrisi untuk penyiraman sehari-hari selama persemaian, dan menyiapkan bahan stek untuk pembibitan sesuai perlakuan. Peubah terpilih pada tanaman yang diamati adalah: saat kemunculan tunas, jumlah cabang yang tumbuh, jumlah daun (setelah 1 bulan), berat daun segar dan kering, serta luas daun. Data yang didapatkan diolah secara statistik dengan menggunakan sidik ragam (Uji F) pada jenjang nyata $5 \%$ dan $1 \%$. Pengujian lanjutan terhadap rata-rata perlakuan dilakukan dengan Uji Jarak Berganda Duncan pada jenjang nyata 5\%.

\section{HASIL DAN PEMBAHASAN}

Penggunaan tanaman obat (medicinal plants) menjadi populer di masyarakat karena adanya semangat untuk "kembali ke alam" pada akhir-akhir ini. Pengobatan dengan memanfaatkan tanaman obat (simplisia) telah diakui khasiatnya, karena memiliki banyak manfaat dan dengan efek samping yang minimal. Dengan semakin maraknya pengobatan secara herbal maka kebutuhan terhadap bahan mentah tanaman oabt-obatan menjadi meningkat. Begitu juga dengan pengadaan tanaman handeuleum yang sangat berguna terutama untuk pengobatan penyakit wasir. Untuk itulah penelitian ini mencoba menyajikan metode pengembangan berupa perbanyakan tanaman handeuleum (Graptophyllum pictum, L.) secara vegetatif dengan menggunakan stek batang.

Tabel 1: Pengaruh macam asal stek dan macam media terhadap beberapa parameter pengamatan pada bibit.

\begin{tabular}{|c|c|c|c|c|c|}
\hline \multirow[t]{2}{*}{ Peubah } & \multirow{2}{*}{$\begin{array}{c}\text { Macam asal } \\
\text { stek }\end{array}$} & \multicolumn{3}{|c|}{ Macam media tanam } & \multirow[t]{2}{*}{ Rata-rata } \\
\hline & & $\mathrm{M}_{1}$ & $\mathrm{M}_{2}$ & $\mathrm{M}_{3}$ & \\
\hline \multirow{4}{*}{$\begin{array}{c}\text { Saat kemunculan } \\
\text { tunas } \\
\text { (hari) }\end{array}$} & $\mathrm{S}_{1}$ & 12,00 & 12,00 & 11,89 & 11,41 \\
\hline & $\mathrm{S}_{2}$ & 10,33 & 10,33 & 11,22 & 10,92 \\
\hline & $\mathrm{S}_{3}$ & 10,78 & 10,78 & 10,56 & 10,56 \\
\hline & Rata-rata & 10,04 & 10,63 & 11,22 & \\
\hline \multirow[t]{4}{*}{ Jumlah daun } & $\mathrm{S}_{1}$ & 4,22 & 4,22 & 3,89 & $4,11 \mathrm{a}$ \\
\hline & $\mathrm{S}_{2}$ & 5,44 & 4,67 & 5,22 & $5,11 \mathrm{~b}$ \\
\hline & $\mathrm{S}_{3}$ & 4,67 & 5,33 & 7,44 & $6,30 \mathrm{c}$ \\
\hline & Rata-rata & 4,78 & 4,74 & 5,52 & \\
\hline \multirow[t]{4}{*}{ Jumlah cabang } & $\mathrm{S}_{1}$ & 1,00 & 1,00 & 1,00 & $1,00 \mathrm{a}$ \\
\hline & $\mathrm{S}_{2}$ & 1,56 & 1,22 & 1,22 & $1,33 \mathrm{~b}$ \\
\hline & $\mathrm{S}_{3}$ & 1,46 & 1,33 & 1,78 & $1,53 \mathrm{c}$ \\
\hline & Rata-rata & 1,34 & 1,18 & 1,33 & \\
\hline \multirow{4}{*}{$\begin{array}{c}\text { Berat daun segar } \\
\text { (g) }\end{array}$} & $\mathrm{S}_{1}$ & 1,34 & 1,09 & 1,33 & 1,25 \\
\hline & $\mathrm{S}_{2}$ & 1,01 & 0,66 & 1,01 & 0,89 \\
\hline & $\mathrm{S}_{3}$ & 0,94 & 0,70 & 1,24 & 0,96 \\
\hline & Rata-rata & 1,10 & 0,82 & 1,19 & \\
\hline \multirow{4}{*}{$\begin{array}{c}\text { Berat daun kering } \\
\text { (g) }\end{array}$} & $\mathrm{S}_{1}$ & 0,13 & 0,12 & 0,15 & 1,33 \\
\hline & $\mathrm{S}_{2}$ & 0,11 & 0,07 & 0,37 & 0,18 \\
\hline & $\mathrm{S}_{3}$ & 0,41 & 0,19 & 0,13 & 0,73 \\
\hline & Rata-rata & 0,22 & 0,13 & 0,22 & \\
\hline \multirow{4}{*}{$\begin{array}{c}\text { Luas daun tiap } \\
\text { bibit } \\
\left(\mathrm{cm}^{2}\right)\end{array}$} & $\mathrm{S}_{1}$ & 49.89 & 40.67 & 49.60 & $46,72 \mathrm{a}$ \\
\hline & $\mathrm{S}_{2}$ & 37.49 & 16,34 & 37.45 & $30,43 \mathrm{~b}$ \\
\hline & $\mathrm{S}_{3}$ & 34.88 & 34.88 & 46.21 & $38,48 \mathrm{c}$ \\
\hline & Rata-rata & $40,75 \mathrm{~b}$ & $30,45 \mathrm{a}$ & $44,42 \mathrm{c}$ & \\
\hline
\end{tabular}

Keterangan: angka-angka yang diikuti dengan huruf yang sama pada kolom atau baris yang sama menunjukkan tidak beda nyata pada Uji jarak berganda Duncan 5\%. $\mathrm{S}_{1=}$ stek asal pucuk; $\mathrm{S}_{2}=$ stek asal ruas ke dua; $\mathrm{S}_{3}=$ stek asal ruas ke tiga. $\mathrm{M}_{1}=$ media pasir; $\mathrm{M}_{2}=$ media rockwool; $\mathrm{M}_{3}=$ media cocopeat. 
Tri Rahayu, Mohamad Ihsan \& Tri Pamujiasih, 2021. Modifikasi Media Tanam Untuk Meningkatkan Mutu Bibit Handeuleum (Graptophyllum pictum L. (Griff.)) Dari Beberapa Macam Asal Stek. Journal Viabel Pertanian. (2021), 15(2) 83-92

\section{Saat munculnya tunas}

Pengamatan peubah pada tanaman yang diamati pada penelitian ini meliputi beberapa parameter pertumbuhan bibit. Pengaruh perlakuan terhadap kenampakan tunas setelah stek ditanam kemudian diadakan pemeliharaan satu bulan, diamati dengan saat keluar/munculnya tunas. Pada tabel 1 dapat dilihat bahwa waktu munculnya tunas tercepat diperoleh pada kombinasi perlakuan stek asal pucuk dengan media tanam berupa rockwool, dan kombinasi perlakuan stek asal ruas ke tiga dengan media tanam rockwool, yaitu secara rata-rata 10,33 hari dari penanaman. Kemunculan tunas paling lambat terdapat pada kombinasi perlakuan stek asal pucuk dengan media tanam pasir. Dari sidik ragam yang dilakukan terhadap data yang diperoleh, menunjukkan bahwa kedua macam perlakuan yang dicobakan yaitu perlakuan macam asal stek dan macam media tanam yang digunakan tidak berpengaruh nyata terhadap saat munculnya kuncup. Hal ini mirip dengan penelitian yang dilakukan oleh Wiraswati dan Badami (2018) yang menemukan bahwa macam asal stek tanaman kumis kucing tidak berpengaruh secara nyata terhadap saat munculnya tunas. Tampak bahwa bibit yang berasal dari stek ruas ke tiga $\left(\mathrm{S}_{3}\right)$ secara rata-rata lebih cepat memunculkan tunas dibanding dengan yang lain. Di sisi lain media tanam yang berasal dari pasir $\left(\mathrm{M}_{1}\right)$ juga paling cepat menyebabkan kemunculan tunas pada bibit. Pembentukan tunas sangat penting dalam menginisiasi terbentuknya primordia daun karena daun merupakan organ tanaman tempat terdapatnya klorofil dalam jumlah yang banyak. Khlorofil berfungsi sebagai tempat terjadinya proses fotosintesis dalam menghasilkan karbohidrat sebagai sumber makanan bagi pertumbuhan tanaman pada tahap berikutnya (Febriana, 2009).

\section{Jumlah daun}

Jumlah daun rata-rata terbanyak dicapai pada kombinasi perlakuan stek asal ruas ke tiga yang ditanam pada media cocopeat yaitu 7,44 helai. Jumlah daun terendah terdapat pada kombinasi perlakuan stek asal pucuk ditanam pada media cocopeat yaitu 3,89 helai. Pengaruh macam asal stek pada jumlah daun menunjukkan bahwa bahan daun dari perlakuan stek asalo ruas ke tiga $\left(\mathrm{S}_{3}\right)$ paling tinggi jumlah daunnya yaitu 6,30 helai yang berarti berbeda secara signifikan dengan jumlah daun pada perlakuan stek asal ruas ke dua $\left(\mathrm{S}_{2}\right)$ dan stek asal pucuk $\left(\mathrm{S}_{1}\right)$. Pada perlakuan ini, jumlah cabang yang terbentuk banyak menyebabkan jumlah daun yang juga lebih banyak. Hormon auksin biasanya diproduksi tanaman pada bagian pucuk (apikal), karena bagian pucuk bibit dipotong akan menyebabkan auksin tersebut ditranslokasikan ke seluruh bagian tanaman dan terkonsentrasi pada bagian pangkal dan tengah batang, sehingga jumlah tunas akan lebih banyak muncul pada stek asal batang bagian bawah (Utami et al., 2020). Pada perlakuan bibit dengan ruas ke tiga, stek batang yang digunakan lebih tua. Stek yang lebih tua ini akan memacu pertumbuhan akar yang semakin baik, karena di dalamnya terkandung lebih banyak cadangan makanan yang dapat dimanfaatkan sebagai pendukung pertumbuhan akar agar terbentuk lebih panjang dalam jumlah yang lebih banyak (Apriani dan Hartanto, 2015; Wulandari et al., 2017). Akar yang panjang akan mampu menjangkau hara yang berada lebih jauh untuk mendukung pembentukan daun yang lebih banyak. Secara rata-rata media cocopeat memberikan jumlah daun pada bibit yang lebih banyak daripada media pasir ataupun rockwool. Hal ini sama dengan yang diperoleh oleh Mariana (2017) yang meneliti media cocopeat pada pertumbuhan stek nilam. Diduga media cocopeat mampu menciptakan keseimbangan yang baik antara air dan udara, selain kemampuannya menyimpan hara untuk kebutuhan tanaman. 
Tri Rahayu, Mohamad Ihsan \& Tri Pamujiasih, 2021. Modifikasi Media Tanam Untuk Meningkatkan Mutu Bibit Handeuleum (Graptophyllum pictum L. (Griff.)) Dari Beberapa Macam Asal Stek. Journal Viabel Pertanian. (2021), 15(2) 83-92

\section{Jumlah cabang}

Pengamatan terhadap parameter rata-rata jumlah cabang menunjukkan bahwa jumlah cabang tertinggi dicapai pada kombinasi perlakuan stek asal ruas ke tiga yang ditanam pada media cocopeat $(1,78)$ dan yang terendah terdapat pada kombinasi perlakuan stek asal pucuk yang ditanam pada semua media tanam yang dicobakan (pasir, rockwool, dan cocopeat). Secara rata-rata jumlah cabang terbanyak dicapai oleh perlakuan bibit yang berasal dari stek asal ruas ke tiga $\left(\mathrm{S}_{3}\right)$. Oleh karena tidak adanya bagian pucuk, maka auksin mengumpul di bagian bawah pada setiap ketiak daun dan memacu pembentukan tunas yang akan berkembang menjadi cabang. Menurut Hartmann dan Kester (2002) cit. Apriani dan Suhartanto (2015), terjadinya proses morfogenesis yang mengatur pertumbuhan dan diferensiasi pada banyak sel, akan memacu kepada pembentukan organ tanaman termasuk juga adanya pembentukan tunas. Auksin merupakan salah satu hormon endogen yang berpengaruh terhadap kemunculan tunas. Keberadaan tunas yang merupakan tempat konsentrasi hormon auksin secara alami yang selanjutnya akan mempengaruhi pertumbuhan akar (Cahyadi et al., 2017), sehingga akan mempengaruhi keberhasilan stek untuk tumbuh lebih baik.

\section{Berat daun segar}

Data pengamatan terhadap rata-rata berat daun segar menunjukkan berat daun segar yang paling tinggi terdapat pada kombinasi perlakuan stek asal pucuk yang ditanam pada media pasir yaitu 1,34 g, sedangkan berat daun segar terendah dicapai pada perlakuan stek asal ruas ke tiga yang ditananam pada media rockwool yaitu sebesar $0,7 \mathrm{~g}$. Hasil analisis terhadap data dengan menggunakan sidik ragam menunjukkan bahwa baik perlakuan macam asal stek ataupun macam media tanamnya tidak berpengaruh nyata terhadap berat daun segar pada bibit. Perlakuan asal stek berupa stek pucuk secara rata-rata menghasilkan berat daun segar yang lebih tinggi. Hal ini mirip dengan yang didapatkan oleh Sebastian (2019) pada penelitiannya terhadap pertumbuhan stek batang tanaman Tumera sabulata, walaupun juga tidak saling berbeda nyata antar asal stek tersebut. Perlakuan dengan media tanam berupa cocopeat $\left(\mathrm{M}_{3}\right)$ secara rata-rata memberikan berat daun segar lebih tinggi dibanding dengan media tanam tanah pasir ataupun rockwool. Pada media cocopeat ini, kecukupan makanan juga ditunjang oleh kecukupan air tetapi tidak berlimpah, jika dibanding dengan pada media rockwool. Apabila suplai makanan yang berasal dari akar mencukupi maka pertumbuhan organ-organ pertumbuhan yang lain akan lebih baik (Hani, 2020).

\section{Berat daun kering}

Dari data yang diperoleh terhadap berat daun kering sesuai yang ditampilkan pada Tabel 1, berat daun kering tertinggi dicapai pada perlakuan stek asal ruas ke tiga pada media tanam berupa pasir yaitu sebesar 0,41 g, sedangkan berat daun kering daun yang terendah ada pada perlakuan stek asal ruas ke dua pada media tanam berupa rockwool. Dari sidik ragam diperoleh hasil bahwa kedua macam perlakuan yang dicobakan tidak berpengaruh nyata. Data ini tentunya selaras dengan data yang diperoleh pada berat daun segar bibit. Secara rata-rata berat daun segar bibit tertinggi dicapai pada perlakuan yang berasal dari stek pucuk $\left(\mathrm{S}_{1}\right)$ daripada stek ke dua dan stek ke tiga. Hal ini karena daun yang terbentuk memiliki luas daun yang lebih besar walaupun jumlahnya lebih sedikit.

\section{Luas daun}

Luas daun tertinggi dicapai oleh perlakuan stek asal pucuk pada media tanam pasir yaitu sebesar, $49,89 \mathrm{~cm}^{2}$, dan luas daun terendahnya pada perlakuan stek asal ruas ke dua dengan media tanam rockwool $\left(16,34 \mathrm{~cm}^{2}\right)$. Dari uji statistik menggunakan sidik ragam diperoleh hasil bahwa perlakuan macam asal stek dan macam media tumbuhnya 
Tri Rahayu, Mohamad Ihsan \& Tri Pamujiasih, 2021. Modifikasi Media Tanam Untuk Meningkatkan Mutu Bibit Handeuleum (Graptophyllum pictum L. (Griff.)) Dari Beberapa Macam Asal Stek. Journal Viabel Pertanian. (2021), 15(2) 83-92

berpengaruh nyata terhadap parameter luas daun bibit. Pada uji lanjutan dengan menggunakan uji jarak berganda Duncan's pada jenjang nyata 5\%, diperoleh hasil bahwa dari perlakuan stek asal pucuk $\left(S_{1}\right)$ didapatkan luas daun tertinggi yaitu secara rata-rata $46,72 \mathrm{~cm}^{2}$, diikuti dengan perlakuan stek asal ruas ke tiga $\left(\mathrm{S}_{3}\right)$ dengan luas daun $38,48 \mathrm{~cm}^{2}$ dan terendah terdapat pada perlakuan stek asal ruas ke dua $\left(\mathbf{S}_{2}\right)$ dengan luas daun 30,43 $\mathrm{cm}^{2}$, yang ketiganya berbeda secara nyata (Tabel 2). Hal ini berbeda dengan yang didapatkan oleh Lesmana et al. (2018) yang mendapatkan hasil bahwa bibit yang berasal dari stek ruas tengah, memberikan luas daun lebih baik disbanding dengan yang berasal dari stek pucuk atau stek bagian bawah pada tanaman melati.

Tabel 2. Pengaruh macam asal stek bibit terhadap rata-rata luas daun

\begin{tabular}{|c|c|c|}
\hline Perlakuan & $\begin{array}{c}\text { Rata-rata luas daun } \\
\left(\mathrm{cm}^{2}\right)\end{array}$ & Notasi \\
\hline $\begin{array}{c}\mathrm{S}_{1} \\
\text { (stek pucuk) }\end{array}$ & 46,72 & $\mathrm{a}$ \\
\hline $\begin{array}{c}\mathrm{S}_{3} \\
\text { (stek ruas ke tiga) }\end{array}$ & 38,48 & $\mathrm{~b}$ \\
\hline $\begin{array}{c}\mathrm{S}_{2} \\
\text { (stek ruas ke dua }\end{array}$ & 30,43 & $\mathrm{c}$ \\
\hline
\end{tabular}

Keterangan: angka-angka yang diikuti dengan huruf yang sama menunjukkan tidak ada beda nyata pada Uji Duncan 5\%

Perlakuan macam media tanam bibit juga berpengaruh nyata pada luas daun. Selanjutnya dengan menggunakan uji Duncan pada jenjang nyata 5\% diperoleh hasil yatu ketiga macam media tanam yang dicobakan menunjukkan saling berbeda nyata pada peubah luas daun per bibit (Tabel 3). Luas daun tertinggi dicapai pada perlakuan media tanam berupa cocopeat $\left(\mathrm{M}_{3}\right)$ yaitu dengan luas daun rata-rata $44,42 \mathrm{~cm}^{2}$, diikuti oleh perlakuan media pasir $\left(\mathrm{M}_{1}\right)$ dengan luas daun rata-rata $40,75 \mathrm{~cm}^{2}$, dan yang terendah pada media tanam berupa rockwool $\left(\mathrm{M}_{2}\right)$ dengan luas daun rata-rata $30,45 \mathrm{~cm}^{2}$.

Tabel 3: Pengaruh perlakuan macam media tanam terhadap rata-rata luas daun

\begin{tabular}{|c|c|c|}
\hline Perlakuan & $\begin{array}{c}\text { Rata-rata luas daun } \\
\left(\mathrm{cm}^{2}\right)\end{array}$ & Notasi \\
\hline $\begin{array}{c}\mathrm{M}_{3} \\
\text { (Media cocopeat) }\end{array}$ & 44,42 & $\mathrm{a}$ \\
\hline $\begin{array}{c}\mathrm{M}_{1} \\
\text { (Media pasir) }\end{array}$ & 40,75 & $\mathrm{c}$ \\
\hline $\begin{array}{c}\mathrm{M}_{2} \\
\text { (Media rockwool) }\end{array}$ & 30,45 & $\mathrm{c}$ \\
\hline
\end{tabular}

Keterangan: angka-angka yang diikuti dengan huruf yang sama menunjukkan tidak ada beda nyata pada Uji Duncan 5\%

Setiap jenis media yang digunakan memiliki perbedaan bobot dan porositas. Cocopeat bersifat lebih ringan, dengan kepadatan spesifik $0,045 \mathrm{~g} \mathrm{~cm}^{-3}$ dan memiliki berat kering 90 gram/ liter. Cocopeat dapat mengikat dan menyimpan air dengan kuat karena memiliki adaya tampung air yang tinggi yakni hingga mencapai 14,71 kali berat keringnya. Hasriani dkk. cit. Irawan dan Hidayah (2014) juga menyatakan bahwa cococopeat merupakan bahan yang memiliki kemampuan menyimpan kadar air dan retensi air dengan kapasitas masing-masing $119 \%$ dan 695,4\%. Tanah pasir memiliki tekstur yang kasar. Ada 
Tri Rahayu, Mohamad Ihsan \& Tri Pamujiasih, 2021. Modifikasi Media Tanam Untuk Meningkatkan Mutu Bibit Handeuleum (Graptophyllum pictum L. (Griff.)) Dari Beberapa Macam Asal Stek. Journal Viabel Pertanian. (2021), 15(2) 83-92

ruang pori yang besar antar butiran sehingga terbentuk struktur longgar. Dengan kondisi ini membuat tanah pasir memiliki kemampuan mengikat air yang rendah. Tanah pasir memiliki kelebihan dibandingkan dengan rockwool karena pada rockwoll ada kondisi kejenuhan air yang sangat tinggi yang sebenarnya menghambat pertumbuhan akar stek bibit handeuleum. Oleh karena itulah pada perlakuan macam media tumbuh, media cocopeat akan menghasilkan luas daun paling tinggi, diikuti media pasir dan rockwool. Jika dilihat dari kondisi fisiknya, cocopeat memiliki sifat mendekati seperti tanah, dapat menampung air yang tidak terlalu banyak sehingga area pertumbuhan akar dan kecukupan airnya terpenuhi. Cocopeat memiliki kemampuan untuk menahan air cukup kuat sehingga serbuk cocopeat sebagai media tanam memiliki kemampuan memegang air yang cukup tinggi. Hal ini karena pada media ini terdapat pori-pori mikro yang dapat menahan laju infitrasi air karena gaya gravitasi, sehingga menyediakan air lebih banyak. Pasir hanya dapat menahan air lebih sedikit, sehingga lebih sedikit pula kecukupannya bagi pertumbuhan tanaman. Rockwool menyimpan air terlalu banyak yang pada akhirnya menjadi tidak baik untuk pertumbuhan bibit handeuleum.

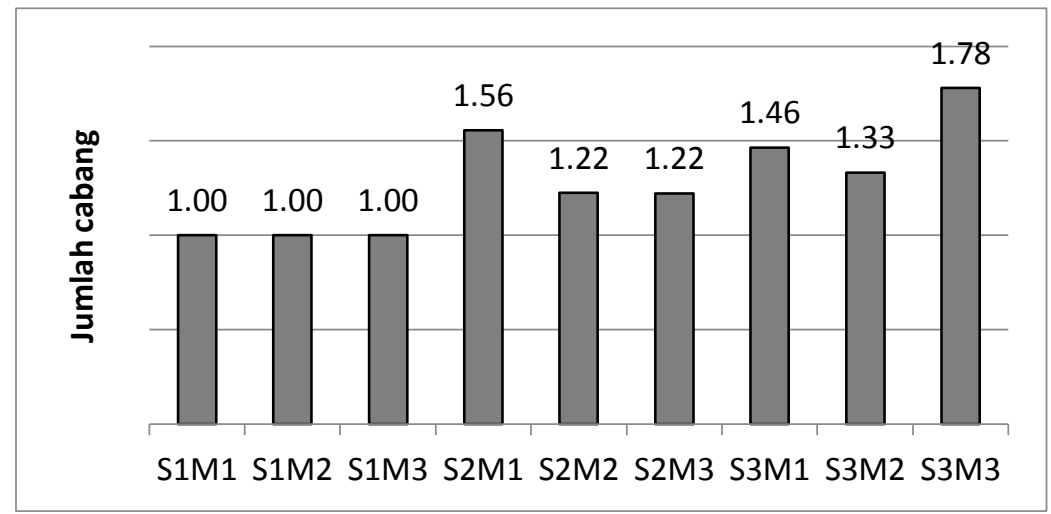

Gambar 1: Pengaruh perlakuan macam asal stek dan macam media terhadap jumlah cabang.

Keterangan: $\mathrm{S}_{1}=$ asal stek pucuk; $\mathrm{S}_{2}=$ asal stek ruas ke dua; $\mathrm{S}_{3}=$ asal stek ruas ke tiga; $\mathrm{M}_{1}=$ media pasir; $\mathrm{M}_{2}=$ media rockwool; $\mathrm{M}_{3}=$ media cocopeat

Kombinasi antara stek yang berasal dari ruas ke tiga dan media pertanaman bibit berupa cocopeat, menghasilkan jumlah cabang yang tertinggi (Gambar 1). Ini menunjukkan bahwa kedua macam perlakuan yang dicobakan memberikan vigor bibit dengan pertumbuhan paling baik.

Dari keseluruhan pengamatan pada percobaan ini, diperoleh hasil bahwa perlakuan macam asal stek berpengaruh secara nyata terhadap jumlah daun, jumlah cabang dan luas daun pada bibit. Perlakuan stek yang berasal dari ruas ke tiga $\left(S_{3}\right)$ menghasilkan jumlah daun dan jumlah cabang tertinggi. Ini terjadi karena pada bagian ini terdapat jaringan yang cukup kuat dan memiliki dua ketiak daun sehingga juga diperoleh jumlah cabang yang paling banyak yaitu rata-rata 1,53 buah. Hal ini menguatkan dugaan tentang adanya dominansi pucuk yang menjadi rusak karena tindakan pemangkasan yang dilakukan. Auksin yang diproduksi oleh tunas apikal akan mengalami proses difusi ke bagian bawah tanaman mengikuti gaya gravitasi sehingga menghambat pertumbuhan tunas-tunas lateral. Tunas-tunas lateral yang berada di bagian bawah yang tadinya dorman, akan terdorong untuk memulai pertumbuhan aqpabila dilakukan pemotongan terhadap tunas apikal. Tunas- 
Tri Rahayu, Mohamad Ihsan \& Tri Pamujiasih, 2021. Modifikasi Media Tanam Untuk Meningkatkan Mutu Bibit Handeuleum (Graptophyllum pictum L. (Griff.)) Dari Beberapa Macam Asal Stek. Journal Viabel Pertanian. (2021), 15(2) 83-92

tunas ini akan terpacu untuk tumbuh karena terjadinya kondisi konsentrasi auksin pada bagian atas yang lebih rendah. Tunas yang berada di ketiak daun menumbuhkan cabang yang akan bersaing membentuk pusat pertumbuhan yang baru (Anonymous, 2016). Jumlah daun secara pasti mengikuti jumlah cabang, karena daunnya tumbuh dari cabang.

\section{KESIMPULAN}

Dari hasil penelitian ini dapat diambil kesimpulan:

1. Perlakuan faktor macam asal stek (S) berpengaruh nyata terhadap peubah jumlah cabang, jumlah daun dan luas daun pada bibit. Jumlah cabang dan jumlah daun tertinggi dicapai dalam perlakuan bahan stek asal ruas ke tiga $\left(S_{3}\right)$, diikuti oleh bahan stek asal ruas ke dua $\left(\mathrm{S}_{2}\right)$, dan bahan stek asal pucuk $\left(\mathrm{S}_{1}\right)$. Luas daun tertinggi dicapai oleh perlakuan stek asal pucuk $\left(\mathrm{S}_{1}\right)$, diikuti oleh stek asal ruas ke dua $\left(\mathrm{S}_{2}\right)$, dan stek asal ruas ke tiga $\left(\mathrm{S}_{3}\right)$.

2. Perlakuan macam media berpengaruh nyata terhadap peubah luas daun. Media tanam berupa cocopeat $\left(\mathrm{M}_{3}\right)$ menghasilkan luas daun tertinggi, diikuti oleh media pasir $\left(\mathrm{M}_{1}\right)$ dan media rockwool $\left(\mathrm{M}_{2}\right)$.

3. Tidak didapatkan adanya interaksi antara perlakuan macam asal bahan stek dan macam media tumbuh pada semua peubah tanaman yang diamati.

\section{SARAN}

Penelitian ini dapat ditindaklanjuti dengan mencoba pertumbuhan bibit handeuleum pada media yang lain termasuk media macam kompos atau media yang banyak terdapat pada masing-masing wilayah.

\section{DAFTAR PUSTAKA}

Anonymous. 2014. Nutrisi Hidroponik AB Mix. http://www.revolusiilmiah.com/20 14/03/nutrisi- hidroponik-ab-mix.html,

-------, 2016. Dominansi Apikal pada Tanaman. Generasi Biologi. http://www.generasi.biologi.com/2016/04/c-pangkas-pangkas-pucukterhadap.html.download3.

Apriani, P. dan M. R. Suhartanto. 2015. Peningkatan Mutu Bibit Torbangun (Plectranthus amboinicus Spreng.) dengan Pemilihan Asal Stek dan Pemberian Auksin. J. Hort. Indonesia 6(2): 109-115. Agustus 2015.

Ashari, S. 2006. Hortikutura Aspek Budi Daya. UI Press Jakarta.

Cahyadi, O., A.M. Iskandar, dan H. Ardian. 2017. Pemberian Rootone F terhadap Pertumbuhan Stek Batang Puri (Mitragyna speciosa Korth). Jurnal Hutan Lestari, 5(2): 191-199.

Cline, M.G.1997. Concept of Terminology of Apical Dominance. American Journal of Botany 84 (9):1064 -1069.

Dalimartha, S. 1999. Atlas Tumbuhan Obat Indonesia. Jilid 1. Trubus Agriwidya, Anggota Ikapi.

Hani, A. 2020. Pengaruh Jenis Stek terhadap Keberhasilan Pembibitan Bambu Hitam (Gigantochloa atroviolaceae Widjaja). Jurnal Litbang Provinsi Jawa Tengah, 18(2): 213-219. 
Tri Rahayu, Mohamad Ihsan \& Tri Pamujiasih, 2021. Modifikasi Media Tanam Untuk Meningkatkan Mutu Bibit Handeuleum (Graptophyllum pictum L. (Griff.)) Dari Beberapa Macam Asal Stek. Journal Viabel Pertanian. (2021), 15(2) 83-92

Irawan, A., H.N. Hidayah. 2014. Kesesuaian Penggunaan Cocopeat sebagai Media Sapih pada Politube dalam Pembibitan Cempaka (Magnolia elegans (Bume) H. Keng)). Jurnal Wasian. 1(2): 73-76.

Irawan, A., Y. Kafiar, 2015. Pemanfaatan Cocopeat dan Arang Sekam Padi sebagai Media Tanam Bibit Cempaka Waisan (Elmerrilia ovalis). Pros. Sem. Nas. Masy. Biodiv Indon. 1(4): 805-808.

Lesmana, I., D. Nurdiana, T. Siswancipto, 2018. Pengaruh Berbagai Zat Pengatur Tumbuh Alami dan Asal Stek Batang terhadap Pertumbuhan Vegetatif Bibit Melati Putih (Jasminum sambac (L.) W. Ait.). Jagros: Jurnal Agroteknologi dan Sains. 2(2): 80-98

Mariana, M. 2017. Pengaruh Media Tanam terhadap Pertumbuhan Stek Batang Nilam (Pogostemon cablin Benth). Agrica Ekstensia. 11(1): 1-8.

Muhit, A., L. Qodriyah. 2006. Respons Beberapa Kultivar Mawar (Rosa hybrida, L.) pada Media Hidroponik terhadap Pertumbuhan dan Produksi Bunga. Buletin Teknik Pertanian 11(1): 29-32.

Pasetriyani, ET. 2014. Pengaruh Macam Media Tanam dan Zat Pengatur Tumbuh Growtone terhadap Pertumbuhan Stek Batang Tanaman Jarak Pagar (Jatropa curcas Linn). Jurnal Agroscience 7(1): 82-88.

Pramono, S. 2002. Kontribusi Bahan Obat Alam dalam Mengatasi Krisis Bahan Obat di Indonesia. Fakultas Farmasi Universitas Gadjah Mada Yogyakarta. Jurnal Bahan Alami Indonesia. 1 (1) Januari.

Sebastianus E. L. Moi, W.D.U. Parwati, N. Andayani. 2017. Pengaruh Macam Bahan Stek dan Komposisi Media Tanam terhadap Pertumbuhan Bibit Turnera subulate. Jurnal Agromast 2(2).

Utami, N., S. Himawati, D.P. Handayani, M. Surachman, A. Tanjung, J.I. Royani. 2020. Keberhasilan Stek Tanaman Lamtoro Varietas Tarramba (Leucaena leucocephala cv. Tarramba) karena Pengaruh Umur Fisiologis dan Zat Pengatur Tumbuh. Pastura, 10(1): 42-45.

Wiraswati, S. F., K. Badami. 2018. Pengaruh Pemberian IBA dan Asal Stek terhadap Pertumbuhan Vegetatif Kumis Kucing. Agrovigor. 11(2):65-70.

Wulandari, F., M. Astiningrum, Tujiyanta. 2017. Pengaruh Jumlah Daun dan Macam Media Tanam pada Pertumbuhan Stek Jeruk Nipis (Citrus aurantifolia Swingle). VIGOR: Jurnal Ilmu Pertanian Tropika dan Subtropika 2 (2): 48 - 51. 